\title{
Site Effect Estimation Using Microtremor Measurements at New Luxor City Proposed Site, South Egypt*
}

\author{
Abdelnasser Mohamed1, Sayed Omer El khateeb², Wael Dosoky#, Mahmoud A. Abbas² \\ ${ }^{1}$ National Research Institute of Astronomy and Geophysics (NRIAG,), Aswan, Egypt \\ ${ }^{2}$ Geology Department, Faculty of Science, South Valley University, Qena, Egypt \\ Email: "wael.desoky@sci.svu.edu.eg
}

How to cite this paper: Mohamed, A., El khateeb, S. O., Dosoky, W., \& Abbas, M. A. (2021). Site Effect Estimation Using Microtremor Measurements at New Luxor City Proposed Site, South Egypt. Journal of Geoscience and Environment Protection, 9, 131-149.

https://doi.org/10.4236/gep.2021.99008

Received: September 1, 2021

Accepted: September 26, 2021

Published: September 29, 2021

Copyright $\odot 2021$ by author(s) and Scientific Research Publishing Inc. This work is licensed under the Creative Commons Attribution International License (CC BY 4.0).

http://creativecommons.org/licenses/by/4.0/

\begin{abstract}
The present study aims mainly at investigating the site effect at the new Luxor city, Egypt, using microtremor measurements. Accordingly, 41 ambient noise recordings were implemented covering the investigated area in a reasonable manner with spacing nearly $1 \mathrm{~km}$ between each measurement station. The data were analyzed using Nakamura's technique. The results show that; the investigated area exhibits low fundamental frequency values ranging between $0.28-0.47 \mathrm{~Hz}$ and its corresponding amplification factor values vary between 2.3 and 6.8. Consequently, the studied site is characterized by the presence of thick soft sediments overlying a hard bed rock. The seismic vulnerability index $(K g)$ was estimated, relying on the estimated fundamental frequency $\left(F_{0}\right)$ and amplification factor $\left(A_{0}\right)$, through the range between 11 and 95 across the mapped area. The obtained $K g$ values were noticed to be compatible with amplification level results. The central part of the investigated area reflects the higher $K g$ and $A_{0}$ values.
\end{abstract}

\section{Keywords}

New Luxor City, Microtremor, Fundamental Frequency, Amplification Factor, Seismic Vulnerability Index (SIV)

\section{Introduction}

The fast growing in the population density, especially its concentration around the river Nile banks, induced the Egyptian government to construct many new cities and urban communities in the new desert areas all over the country. Ac-

${ }^{\star}$ Microtremor measurements at New Luxor city. 
cording to the sustainable development plan of the Upper Egypt, the new Luxor city "study area" is one of the promising projects in south Egypt. The current studied area is existed at the eastern portion of the Nile Valley, $7.5 \mathrm{~km}$ southeast old Luxor city located between latitude $25^{\circ} 34^{\prime} 12^{\prime \prime} \mathrm{N}$ and $25^{\circ} 38^{\prime} 24^{\prime \prime} \mathrm{N}$ and longitudes $32^{\circ} 37^{\prime} 12^{\prime \prime} \mathrm{E}$ and $32^{\circ} 40^{\prime} 00^{\prime \prime} \mathrm{E}$ covering a surface area of about $28 \mathrm{~km}^{2}$. The study area can be considered as the natural expansion of Luxor city (Figure 1).

Unplanned urban development is one of the causes which increase the potential hazards of earthquakes in active seismic areas specially in developing countries like Egypt. The most important factor to mitigate the earthquake hazard is the land use planning of urban areas which are located on or near the active seismic zone such as the proposed site of the new Luxor city.

The new proposed sites for construction need a detailed study of the nature of sediments as being a foundation soil. Many researchers have authenticated that soft sediments can notably magnify seismic waves resulting in detrimental level during an earthquake release (e.g., Singh et al., 1988; Borcherdt et al., 1989). Recent destructive earthquakes (e.g, Michoacan, Mexico in 1985, Kalamata, Greece 1989, Lomaprieta, California, USA 1989, Roodbar-Manjil, Iran 1990, Kocaeli and Duzce Turkey 1999, Chi-Chi, Taiwan area 1999, Bam, Iran 2003, and Wenchuan, China, 2008) have distinctly shown that the local geology conditions have

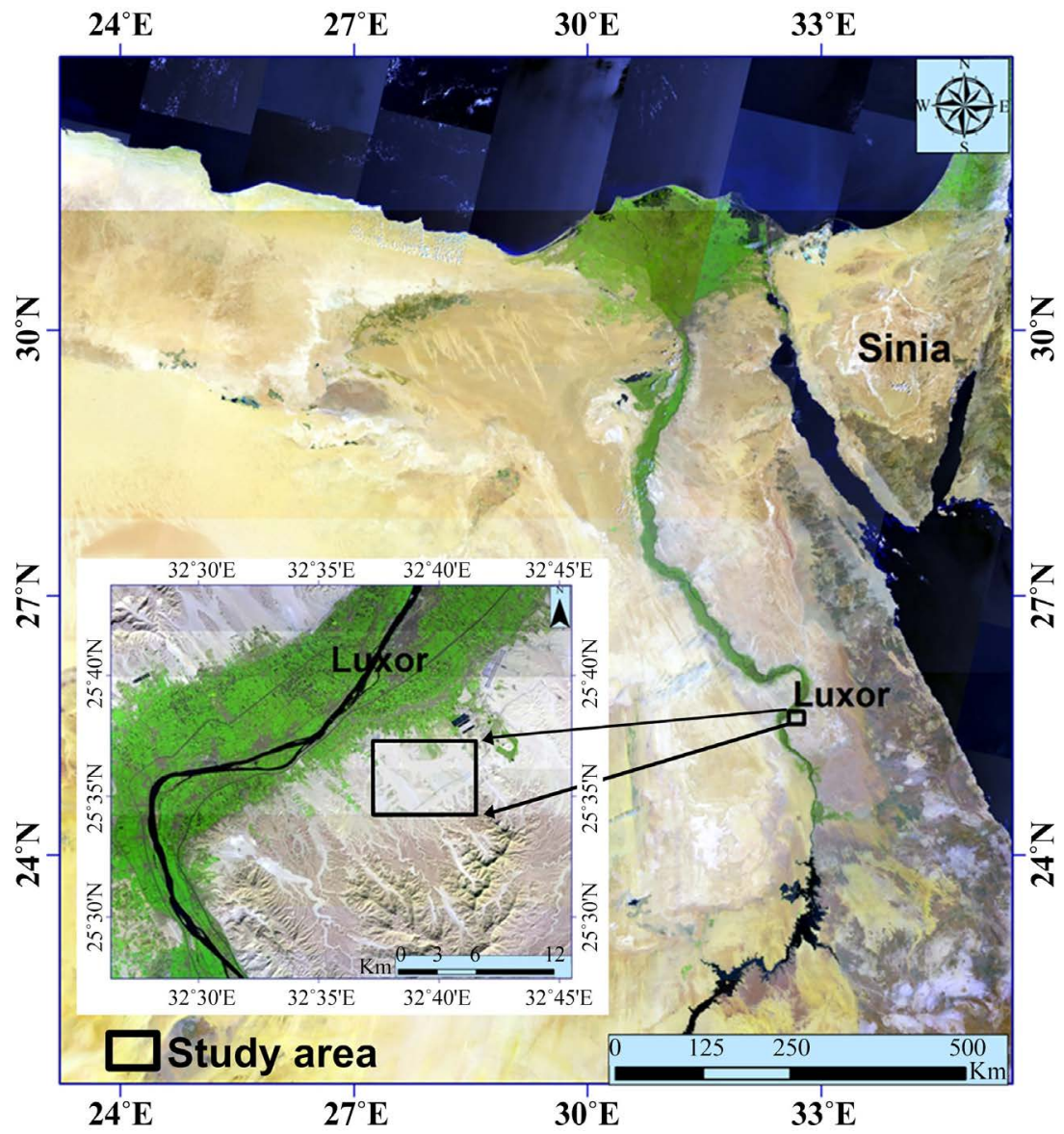

Figure 1. Location map of the investigated area. 
a great effect on magnification of ground motion created by dynamic excitation of earthquake (Ansal et al., 2004). This effect is known as site effect. Bard (2000) concluded that; every location has a particular resonance frequency at which soft deposits can amplify ground motion caused by seismic events. Mukhopadhyay \& Bormann (2004) reported that the man-made infrastructures have a fundamental resonance frequency that coincides with that of a site, then a possibility of damage is expected. So, site effect estimation becomes a major challenge for assessment and mitigation of earthquake hazard in earthquake engineering strategy (Reiter, 1990; Meunier et al., 2008; Panzera et al., 2013).

The horizontal to vertical spectral ratio method, known as Nakamura's technique, is considered a relatively easy, economically attractive, and quick implementation procedure for site response estimation using microtremors measurements. Many researchers implemented Nakamura method to determine the site effect in different parts of Egypt (e.g., Abdel-Rahman et al., 2012; El-Eraki et al., 2012; Abudeif et al., 2019; Fat-Helbary et al., 2019; Mohamed et al., 2013, 2015, 2020; Meneisy et al., 2020). This method was also used in the current study to investigate the potentiality of amplification level of soft sediments and assess the impact of soil conditions at the studied area.

\section{Geological Setting}

The geologic setting of Luxor district was discussed by many authors (Said, 1962, 1981, 1990; Abd El-Rahman, 1980; El Hossary et al., 1994; Kamel, 2004). The stratigraphic units at Luxor area consist mainly of sedimentary origin ranging in age from Upper Cretaceous to Recent (Figure 2). El Hossary et al. (1994) describe the subsurface stratigraphic units of Luxor area (Figure 3). The surface of the investigated area is covered mainly by Quaternary and Pliocene deposits. Quaternary deposits are mainly composed of unconsolidated deposits in the form of sand, gravel, silt, and recent wadi deposits. Pliocene deposits are represented by Madamoud Formation composed of red brown clay, marl, and fine sand and silt lamina.

The geomorphological features in the mapped area include hills, pediment (alluvial) and large wadis. The location of the investigated area is characterized by moderate topography with average ground elevation varies from about $165 \mathrm{~m}$ in the southern part to about $105 \mathrm{~m}$ above sea level at the northern part, as illustrated in Figure 4.

\section{H/V Method (Nakamura's Technique)}

H/V method was introduced firstly by Nogoshi and Igarashi (1971) and then modified by Nakamura (1989). This method is called also Nakamura method. It depends mainly on using three components' sensors at one single station to record microtremors; one of them is the vertical component and the others are the orthogonal horizontal components. By estimation of the Fourier spectral amplitude ratio between the horizontal and vertical components, then the site response parameters can be obtained (Molnar et al., 2018). 


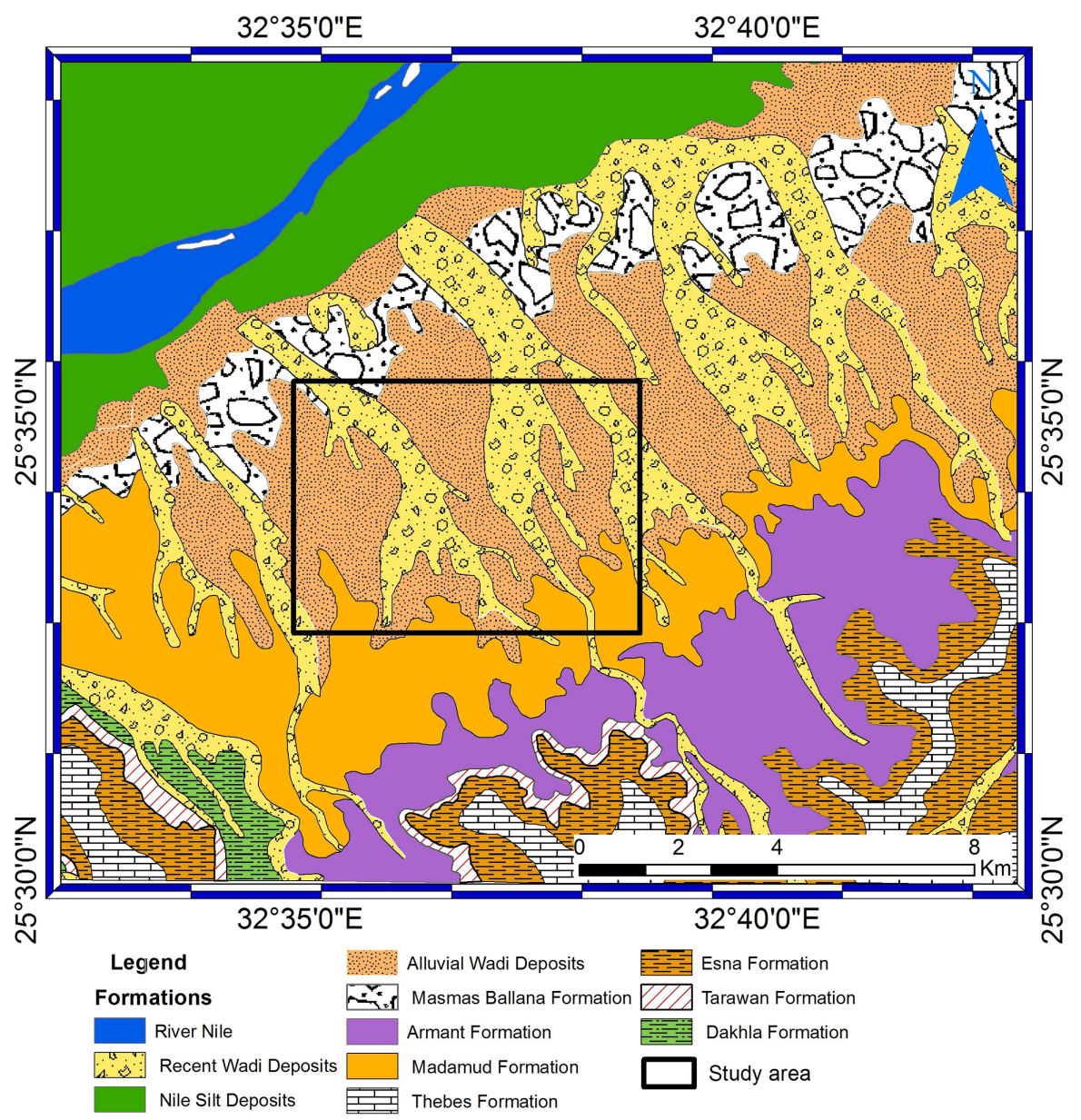

Figure 2. Geologic map of Luxor area included within the investigated area (modified after Ministry of industry and Mineral Resources previously EGSMA, 2006).

The conception principles of Nakamura's method can be illustrated in an easiest case, in 1D loose sedimentary layer (soil) overlies hard rock (bed rock). Figure 5 shows a typical sedimentary basin, where H/V spectral ratio can be calculated from ambient noise based on Nakamura's technique. In this case, site effects (transfer function) due to surface geology can be given by the spectral ratio between recording signal on the surface and the ones at bedrock.

The transfer function of the surface layers is $S_{T}$ is defining as:

$$
S_{T}=\frac{H_{S}}{H_{B}}
$$

where $H_{S}$ and $H_{B}$ are the horizontal amplitude spectrum at the surface layer and bedrock respectively.

The Nakamura's technique is based on the following assumption: 1) a horizontal less rigidity sedimentary layer overlying a more rigidity bed rock 2) several waves comprise microtremors, but Rayleigh waves propagation in loose surface layer is the predominately; 3) The effect of Raleigh waves $E_{S}$ on noise movement is limited to the vertical spectrum of the surface layer $V_{S}$ only and does not include the vertical spectrum at the bedrock $V_{B}$. 4) Vertical waves are 


\begin{tabular}{|c|c|c|c|c|c|c|}
\hline \multicolumn{3}{|c|}{ Age } & \multirow{3}{*}{ 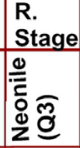 } & \multirow[t]{2}{*}{ Formation } & \multirow{2}{*}{ 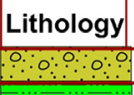 } & \multirow{2}{*}{$\begin{array}{l}\text { Description } \\
\text { Gravel and sand }\end{array}$} \\
\hline \multirow{9}{*}{ 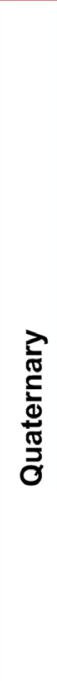 } & \multirow{2}{*}{ 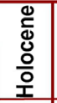 } & & & & & \\
\hline & & & & Arkin & & Silty clay of cultivated land \\
\hline & \multirow{7}{*}{ 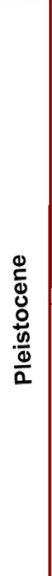 } & \multirow{4}{*}{ 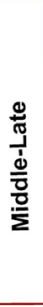 } & \multirow{4}{*}{ 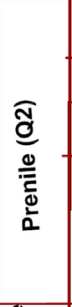 } & Abbassia & & Conglomerate \\
\hline & & & & Dandara & & Sandy silt and clay \\
\hline & & & & Abbassia & & Conglomerate \\
\hline & & & & Qena & & $\begin{array}{l}\text { Massive cross-bedded sand } \\
\text { with clay lenses }\end{array}$ \\
\hline & & \multirow{3}{*}{ 产 } & 岸 & Issawia & & Tuffa, red breccia and sand \\
\hline & & & 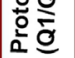 & Armant & & Clay, sand and conglomerate \\
\hline & & & 吾 & Idfu & & $\begin{array}{l}\text { Cobbles and gravels in } \\
\text { red clay matrix }\end{array}$ \\
\hline \multirow{5}{*}{ 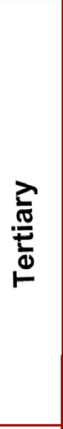 } & \multirow{2}{*}{ 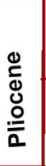 } & $\stackrel{ \pm}{ \pm}$ & 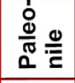 & Madmud & & $\begin{array}{l}\text { Red brown clay, sand, silt } \\
\text { and marl }\end{array}$ \\
\hline & & & 촐 & M.Seq. & & Clay and sand \\
\hline & 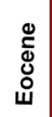 & 촐 & (Te) & Thebes & & $\begin{array}{l}\text { Chalky limestone bed with } \\
\text { chert bands }\end{array}$ \\
\hline & \multirow{2}{*}{\multicolumn{2}{|c|}{ 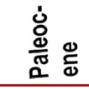 }} & \multirow[t]{2}{*}{ (TP) } & Esna & & Marls and shales \\
\hline & & & & Tarwan & 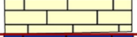 & Chalks \\
\hline \multirow{3}{*}{ 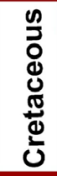 } & \multirow{3}{*}{\multicolumn{2}{|c|}{ 苋 }} & Kda & Dakhla & & Chalk and marls \\
\hline & & & Kdu & Duwi & & Marls, shales, and phosphates \\
\hline & & & Kn & Nubian & 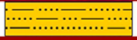 & Sandstone with shale \\
\hline
\end{tabular}

Figure 3. Stratigraphic succession of Luxor area (after El Hossary et al., 1994).

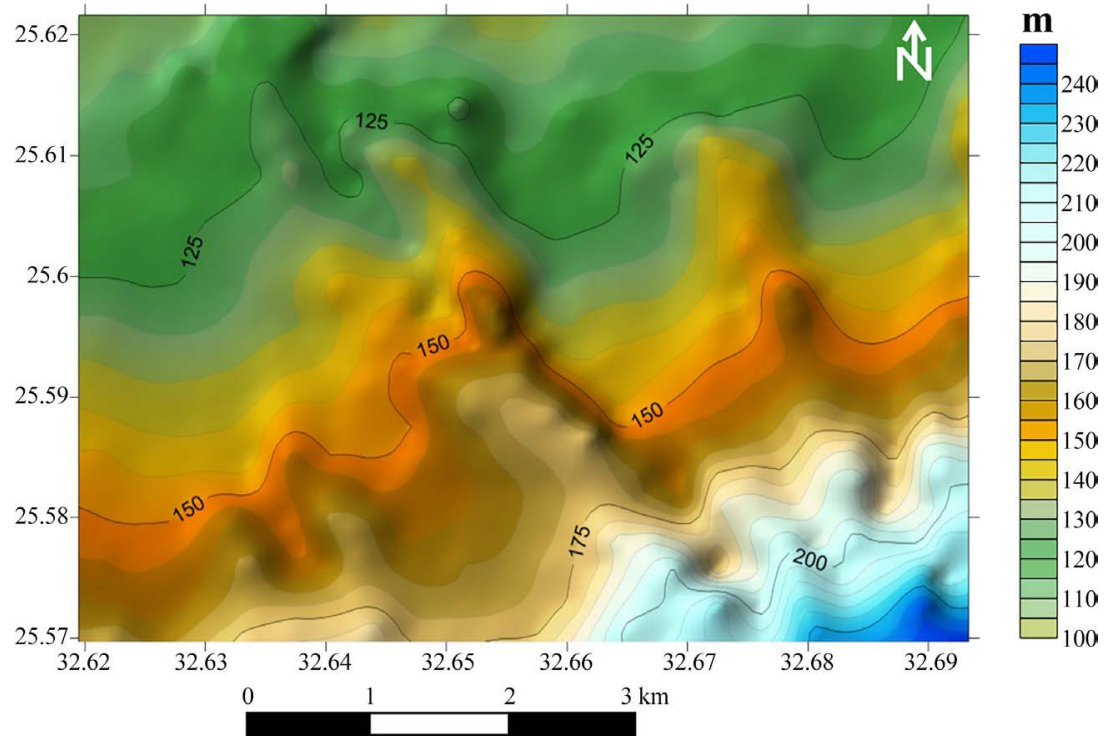

Figure 4. Topographic map of the investigated area. 


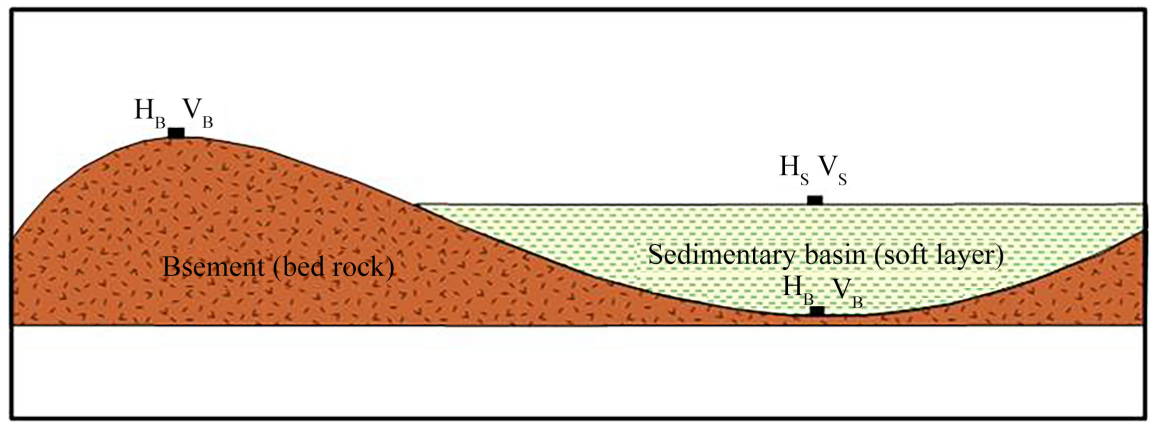

Figure 5. A typical sedimentary basin, where $\mathrm{H} / \mathrm{V}$ spectral ratio can be calculated from microtremors (after Nakamura, 2000).

not amplified by soft deposits; hence, the effect of Rayleigh waves on the vertical tremor on the vertical motion at the surface and bedrock is;

$$
E_{S}=\frac{V_{S}}{V_{B}}
$$

Follow these assumptions the transfer function of the surface layer $S_{M}$ after elimination of the effect of Rayleigh waves can be expressed as:

$$
S_{M}=\frac{S_{T}}{E_{S}}
$$

Substituting (1) and (2) in Equation (3) we get:

$$
S_{M}=\frac{H_{S} / H_{B}}{V_{S} / V_{B}}
$$

where

$$
\frac{H_{B}}{V_{B}}=1
$$

The site effect function can be written as:

$$
S_{M}=\frac{H_{S}}{V_{S}}
$$

The last equation emphases that, the transfer function of the surface layer (H/V spectral ratio) can be estimated from tremor recorded at the surface only. This method effectively can be used for estimation of site response parameters (peak frequency $F_{0}$ and corresponding amplification factor $A_{0}$ ) (Nakamura, 1989; Milana et al., 2011).

\section{Microtremor Data Acquisition and Processing}

Microtremors survey of single station ambient oscillation recordings were executed during December 2020 at the proposed New Luxor city location. A total of 41 Microtremors measurements sites covered the study area with spacing nearly $1 \mathrm{~km}$ between stations. The locations of the measured sites are shown in Figure 6 . Microtremors data were acquired during the day time using three component Trillium compact $120 \mathrm{~s}$ seismometers and Taurus digitizer recorder (Figure 7). 
The seismometer discloses ground motion and outputs a signal representing ground velocity. A 12-volt marine battery was used to power the seismometer. At each measurement site, seismometer was vertically levelled with good coupling with ground and oriented to the north direction. Levelling and orienting the seismometer is required to achieve accurate recordings for each component, horizontal (north-south and east-west) and vertical. A GPS receiver was used to identify the latitude-longitude of each site and to establish the timing and duration of each recording. Recordings were made at 100 samples per second. A duration ranging between 90 min to 2 hours were spent on each site for continues noise signal recording. For dependable experimental conditions, the guidelines proposed in the SESAME project (SESAME, 2004) were accurately followed.

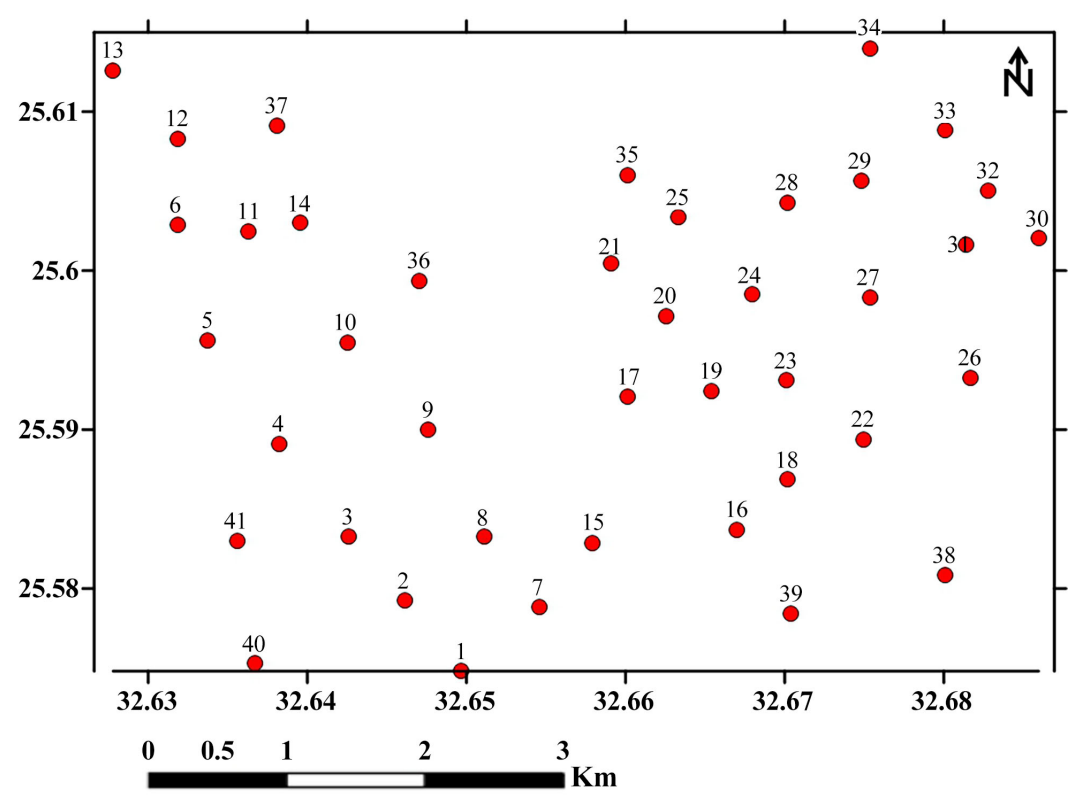

Figure 6. Locations of H/V measurement stations at the investigated area.

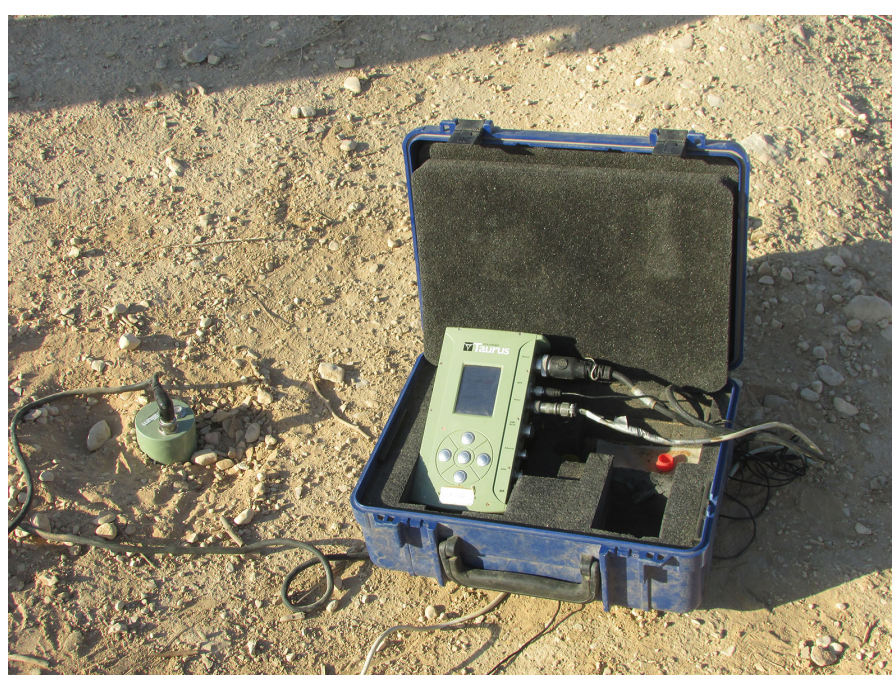

Figure 7. The Trillium 120 s seismometer with Taurus seismograph used during data acquisition. 
Geopsy software initiated by SESAME project (SESAME, 2004)

(http://www.geopsy.org) were used for data analysis by applying H/V spectral ratio Nakamura's technique (Nakamura, 1989). In the present study the data analysis is focused on the frequency range between 0.2 and $20 \mathrm{~Hz}$.

Ambient noise record signal was subdivided into time windows with 70 second duration (for each site, at least 15 windows were used). Each time window was choosen using the automatic window selection option of the Geopsy software depends on STA/LTA ratio anti-triggering algorithm for discarding any transient signal (e.g. close traffic, footsteps, etc), then the selected signal contain only real seismic ambient vibration (SESAME, 2004; Wathelet, 2010). An example of Windows selection in Geopsy software illustrated in Figure 8. The time series was tapered with a $8 \%$ cosine taper, and the fast Fourier transform (FFT) was used for computed the amplitude spectrum for all three component. The algorithm of Konno and Ohmachi (1998) was used for smoothing of these FFT spectra with a band width coefficient value equal to 40.The advantages of the smoothing option of the spectra as illustrated by several researchers (e.g., Bindi et al., 2000; Picozzi et al., 2005), are stabilizing of H/V curves as well as avoiding the presence of superior peaks due to interference of external transient noise.

Finally, merging and averaging of the two horizontal components were made using geometric mean option to get the outcome $H$ components as the following equation:

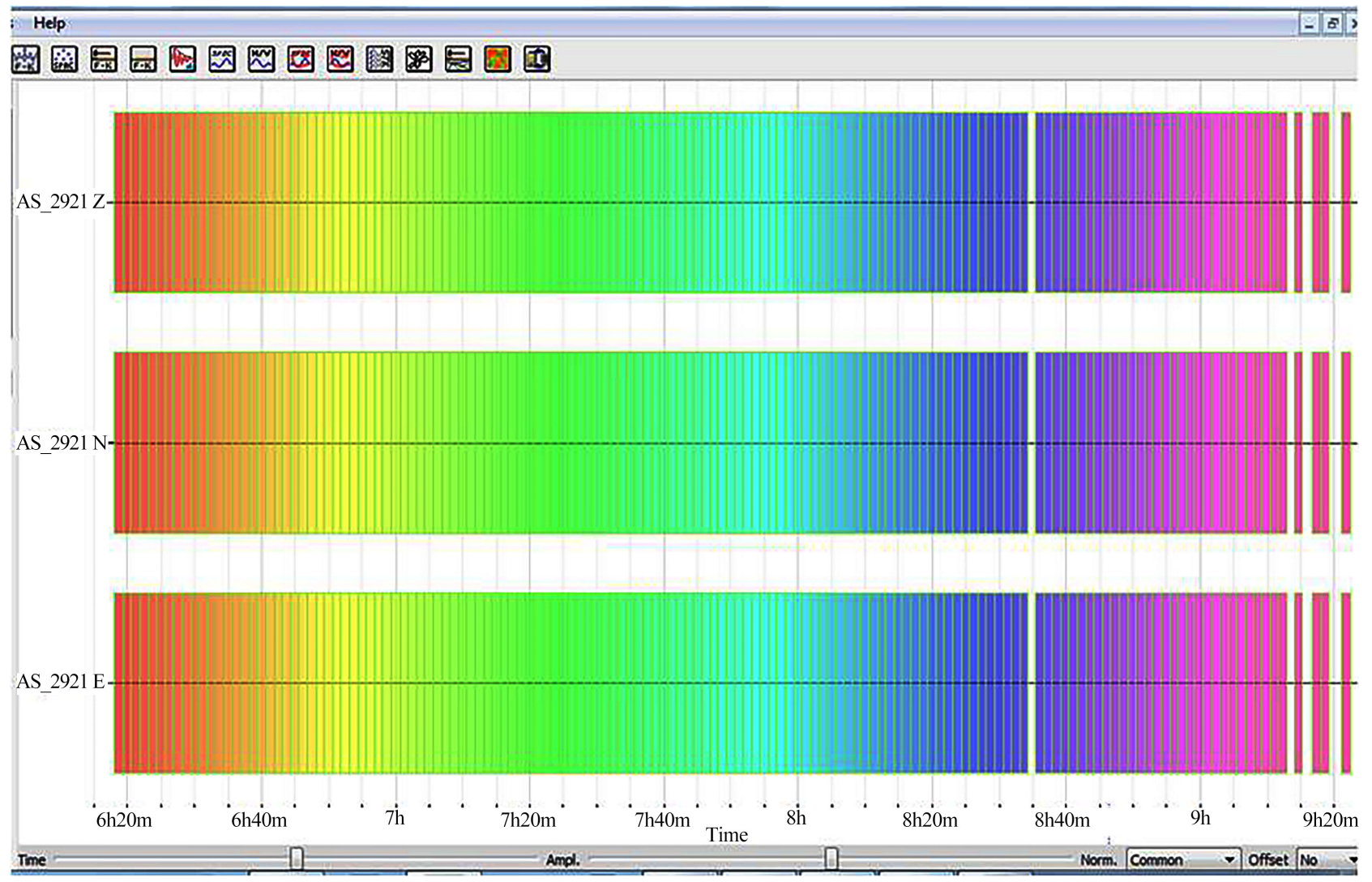

Figure 8. Windows selection in Geopsy software for the recorded microtremor data at site No. 23. 


$$
H=\left(\left|x_{f} \cdot y_{f}\right|\right)^{0.5}
$$

where: $(H)$ is the geometric mean for the two horizontal components, $\left(x_{f}\right)$ is the spectral modulus of the North-South components and $\left(y_{f}\right)$ is the spectral modulus of East-West component. The horizontal components spectra were merged then divided by the vertical component spectra, then the horizontal spectral ratios can be calculated. The amplitude spectra for the three components was estimated (Figure 9). For each site, H/V spectra ratio curves were calculated, which enables determination of the most critical site response parameters $\left(F_{0}\right.$ and $\left.A_{0}\right)$. Finally, all peaks of HVSR curves were neatly inspected and tested for identify their origin (natural or industrial) through performed these testes.

Application of the random decrement technique on the microtremors recording data is intended mainly to infer the impulse response around the frequency of concern: in the case of industrial origin, the damping $(Z)$ will be very low (less than 1\%), such peaks excluded from the results (Dunand et al., 2002).

Applying the spectrum rotation for the horizontal components. The direction of energy release can be checked by this test.

The whole recorded data were subjected to the above-mentioned tests and all peaks were of natural origin. Examples of application of these tests are illustrated in Figure 10 \& Figure 11).

\section{Results and Discussion}

Nakamura's technique is established on the presence of a soft sediments layer overlying another hard bedrock layer. In this case, the H/V spectral ratio usually shows a peak, which matches the fundamental frequency $\left(F_{0}\right)$ of the site and the corresponding peak amplitude $\left(A_{0}\right)$. The present work involves estimating the site response parameters viz $\left(F_{0}\right.$ and $\left.A_{0}\right)$ for about 41 measuring points distributed across the mapped area and the obtained results are recorded in Table 1.

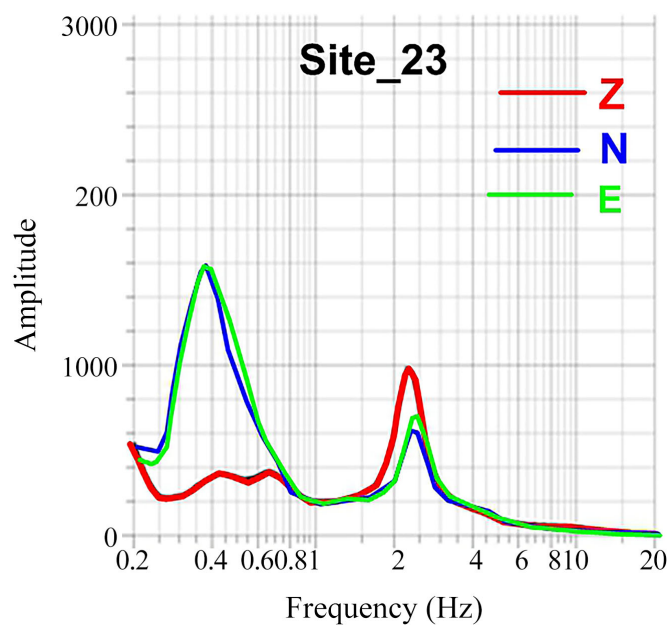

Figure 9. Representative example of amplitude spectrum of the three components at site No. 23. 


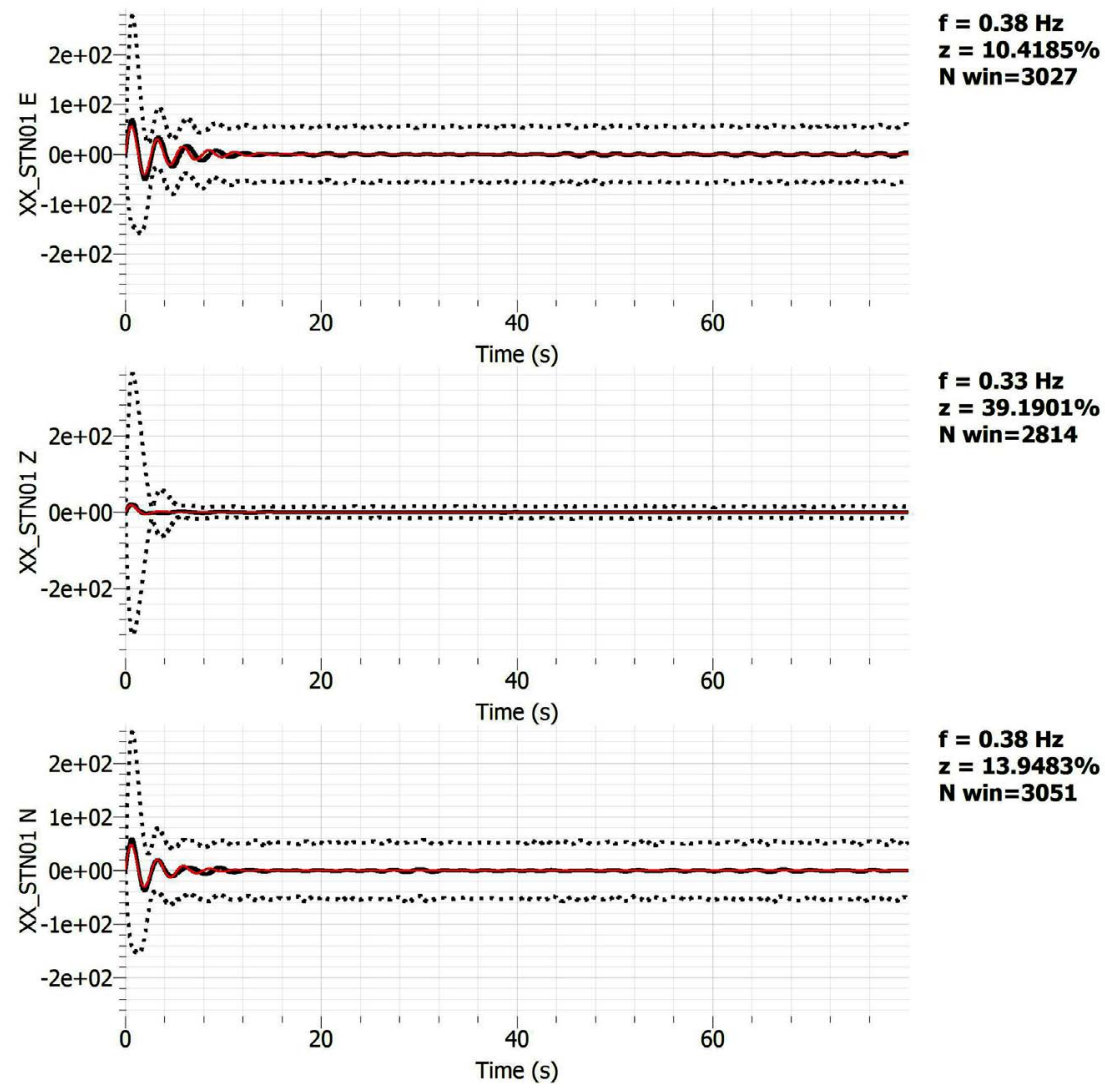

Figure 10. Example of damping test for the peak amplitude at site No. 8 .

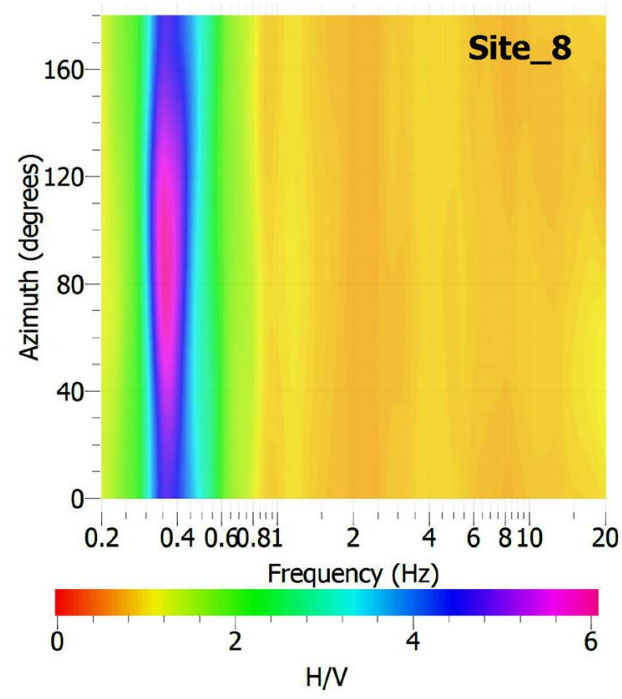

Figure 11. Example $\mathrm{H} / \mathrm{V}$ rotation with azimuth test at site No. 8 .

Table 1. The obtained results from HVSR survey at the study area.

\begin{tabular}{ccccccc}
\hline Site. No & Long. & Lat. & $F_{0}$ & $A_{0}$ & $K g$ & $h(\mathrm{~m})$ Abdel-aal (2018) \\
\hline 1 & 32.64964 & 25.57481 & 0.46 & 3.28 & 23.38783 & 277.4 \\
2 & 32.64614 & 25.57928 & 0.42 & 3.42 & 27.84857 & 316.6
\end{tabular}


A. Mohamed et al.

\section{Continued}

\begin{tabular}{|c|c|c|c|c|c|c|}
\hline 3 & 32.64261 & 25.58325 & 0.39 & 4.68 & 56.16 & 352.5 \\
\hline 4 & 32.63825 & 25.58908 & 0.35 & 4.19 & 50.16029 & 412.4 \\
\hline 5 & 32.63375 & 25.59562 & 0.33 & 3.26 & 32.20485 & 449.1 \\
\hline 6 & 32.63183 & 25.60289 & 0.29 & 3.88 & 51.91172 & 541.7 \\
\hline 7 & 32.65461 & 25.57883 & 0.47 & 2.28 & 11.06043 & 268.9 \\
\hline 8 & 32.65111 & 25.58328 & 0.37 & 4.72 & 60.21189 & 380.4 \\
\hline 9 & 32.64761 & 25.59 & 0.37 & 4.31 & 50.20568 & 380.4 \\
\hline 10 & 32.6425 & 25.59544 & 0.33 & 4.47 & 60.54818 & 449.1 \\
\hline 11 & 32.63628 & 25.60244 & 0.32 & 4.33 & 58.59031 & 469.6 \\
\hline 12 & 32.63183 & 25.60831 & 0.28 & 3.65 & 47.58036 & 569.9 \\
\hline 13 & 32.62781 & 25.61258 & 0.28 & 3.87 & 53.48893 & 569.9 \\
\hline 14 & 32.63955 & 25.60299 & 0.29 & 4 & 55.17241 & 541.7 \\
\hline 15 & 32.65792 & 25.58289 & 0.38 & 4.9 & 63.18421 & 366.1 \\
\hline 16 & 32.66702 & 25.58372 & 0.42 & 3.62 & 31.20095 & 316.6 \\
\hline 17 & 32.66013 & 25.59204 & 0.35 & 3.79 & 41.04029 & 412.4 \\
\hline 18 & 32.67019 & 25.58689 & 0.4 & 3.84 & 36.864 & 339.8 \\
\hline 19 & 32.66539 & 25.5924 & 0.41 & 3.26 & 25.92098 & 327.8 \\
\hline 20 & 32.66252 & 25.59715 & 0.32 & 4.15 & 53.82031 & 469.6 \\
\hline 21 & 32.65906 & 25.60044 & 0.3 & 3.9 & 50.7 & 515.7 \\
\hline 22 & 32.67497 & 25.58936 & 0.42 & 3.9 & 36.21429 & 316.6 \\
\hline 23 & 32.67011 & 25.5931 & 0.33 & 5.6 & 95.0303 & 449.1 \\
\hline 24 & 32.66796 & 25.5985 & 0.31 & 4.26 & 58.54065 & 491.7 \\
\hline 25 & 32.66333 & 25.60334 & 0.3 & 6.81 & 154.587 & 515.7 \\
\hline 26 & 32.68169 & 25.59325 & 0.42 & 3.37 & 27.04024 & 316.6 \\
\hline 27 & 32.67539 & 25.59828 & 0.38 & 3.12 & 25.61684 & 366.1 \\
\hline 28 & 32.67017 & 25.60427 & 0.33 & 3.97 & 47.7603 & 449.1 \\
\hline 29 & 32.67481 & 25.60562 & 0.31 & 3.88 & 48.56258 & 491.7 \\
\hline 30 & 32.68595 & 25.60204 & 0.47 & 2.34 & 11.65021 & 268.9 \\
\hline 31 & 32.68139 & 25.60161 & 0.42 & 3 & 21.42857 & 316.6 \\
\hline 32 & 32.6828 & 25.605 & 0.47 & 2.86 & 17.4034 & 268.9 \\
\hline 33 & 32.6801 & 25.60883 & 0.32 & 4.14 & 53.56125 & 469.6 \\
\hline 34 & 32.67536 & 25.61399 & 0.35 & 3.12 & 27.81257 & 412.4 \\
\hline 35 & 32.66015 & 25.60602 & 0.32 & 3.6 & 40.5 & 469.5 \\
\hline 36 & 32.64706 & 25.59935 & 0.31 & 4.44 & 63.59226 & 491.7 \\
\hline 37 & 32.63808 & 25.60914 & 0.28 & 2.94 & 30.87 & 569.9 \\
\hline 38 & 32.68009 & 25.58086 & 0.44 & 2.69 & 16.44568 & 295.9 \\
\hline 39 & 32.67036 & 25.57845 & 0.38 & 3.94 & 40.85158 & 366.1 \\
\hline 40 & 32.63672 & 25.57528 & 0.43 & 4.23 & 41.6114 & 305.9 \\
\hline 41 & 32.63558 & 25.58296 & 0.38 & 3.6 & 34.10526 & 366.1 \\
\hline
\end{tabular}


The obtained HVSR curves mostly reflect a single peak (Figure 12) while few sites show two peaks (Figure 13). The corresponding frequency of HVSR curves was considered to be the dominant frequency $\left(F_{0}\right)$ within a single peak case. Moreover, HVSR curves which show two various frequency peaks, in this case the peak of maximum amplitude is considered to be $F_{0}$ and the other peak probably attributed to the presence of a shallow depth impedance contrast.
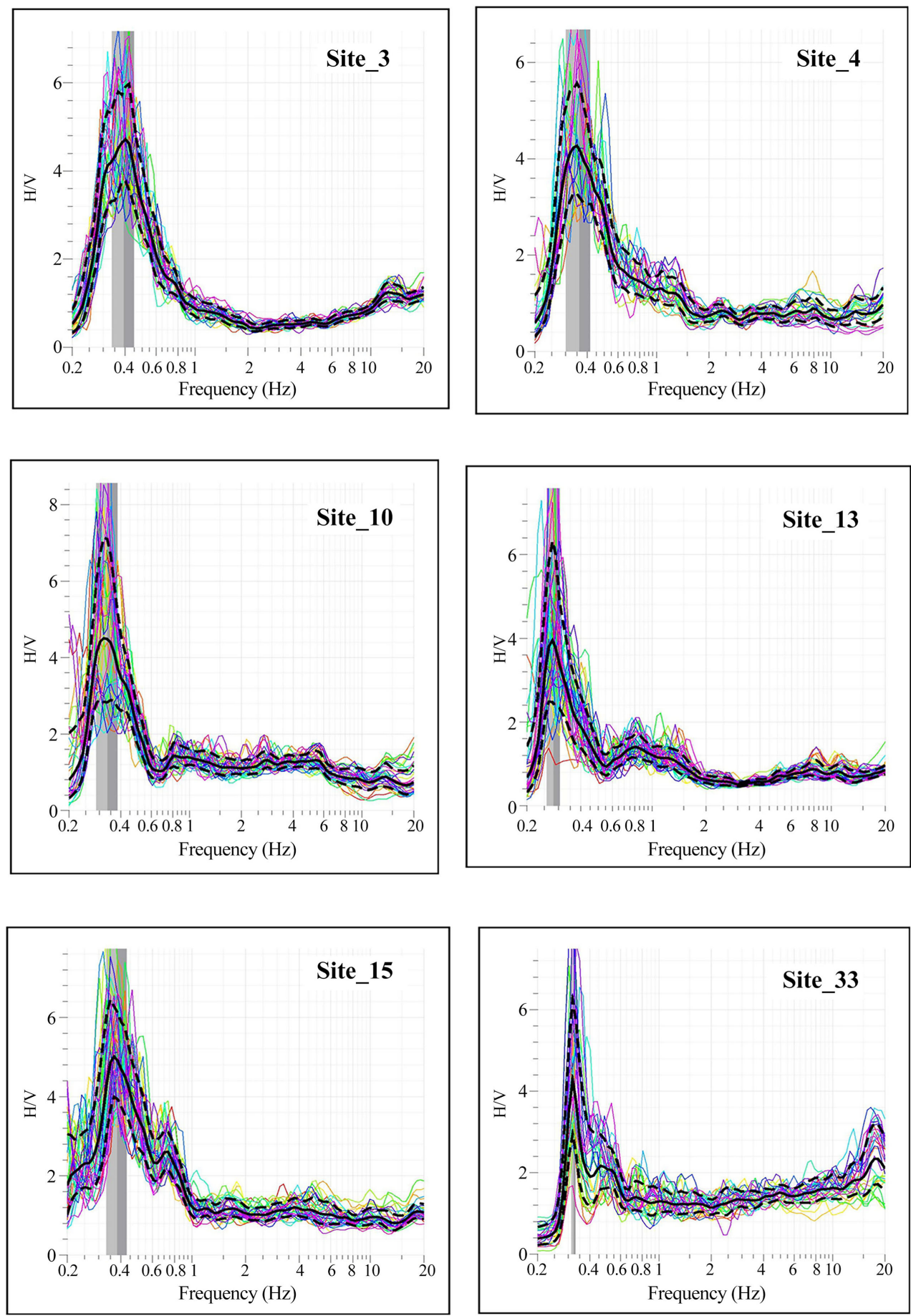

Figure 12. Example of H/V curves with Single clear peak. 

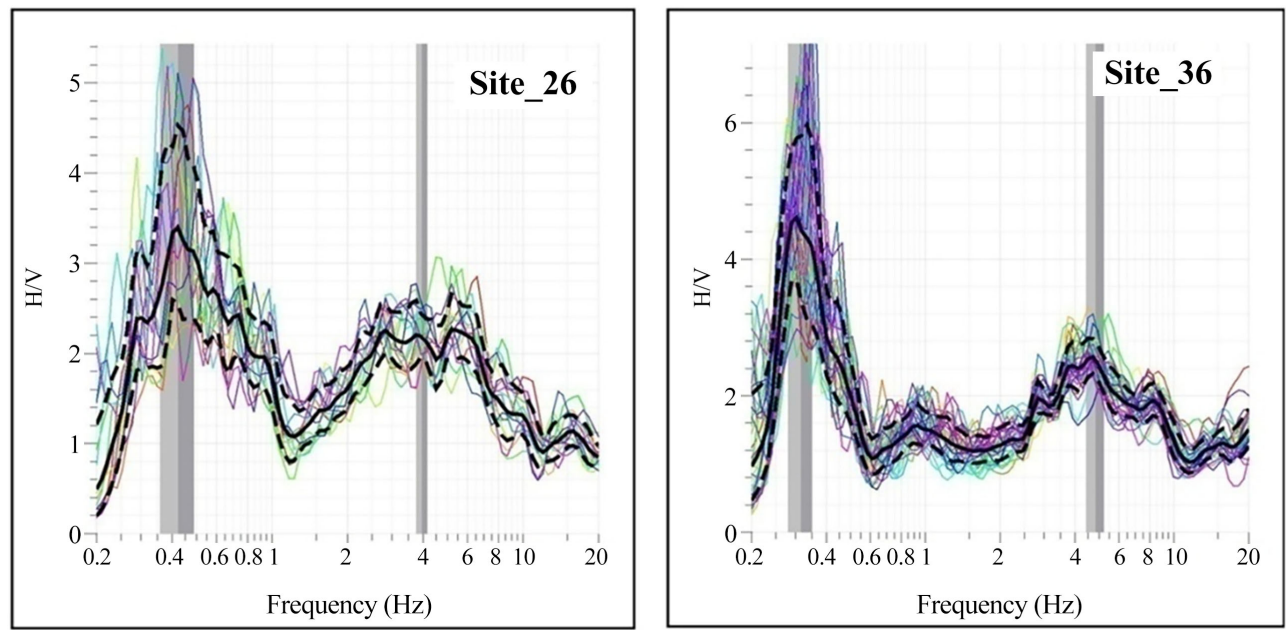

Figure 13. H/V curves shows two peaks at diverse frequencies at study area.

Through performing spatial interpolation between the estimated resonance frequency $F_{0}$ and amplification level $A_{0}$ values at each measurement site, a map for resonance frequency (Figure 14) and another map for the maximum amplification (Figure 15) were created. Most of the studied area exhibit low resonance frequency values $<0.5 \mathrm{~Hz}$ ranging between 0.28 and $0.47 \mathrm{~Hz}$ with slight gradual decrease from southeast to northwest in the direction of the Nile valley (Figure 14). Generally, the low fundamental frequencies $\left(F_{0}<0.5 \mathrm{~Hz}\right)$ of the study area can be attributed to the measured sites which are located in an alluvial plain zone occupied by thick cover of the soft Quaternary and Pliocene sediments (gravel, sand, silt, and clay). The thickness of such deposits was estimated (Table 1), using the formula $h=90 F_{0}-1.45 \pm$ (0.02) derived by Abdel-aal (2018), through the range between 269 and $570 \mathrm{~m}$. The zonation map of H/V spectral ration amplitude $A_{0}$ (Figure 15) illustrates that; the amplifications factor is generally varies between 2.3 and 6.8 with a higher values observed at the central part of the area. Ground amplification level of the site has been governed by impedance disparity between loose sediments cover overlying a rigid bedrock, where the areas having large impedance disparity value reflects the higher values of amplification (SESAME, 2004; Gosar, 2017; Molnar et al., 2018). The amplitude level more than 2 indicates the presence of site amplification, whereas no amplification in the case of amplitude level less than 2 or flat HVSR curves (SESAME, 2004). Toward the foothill as reported in the southern part of the area, the HVSR peak amplitudes are lower than those located in alluvial zone or wadis such as the middle part area (Burjanek et al., 2014).

The seismic vulnerability index values (SIV) were estimated at each site (Table 1) using the formula $K g=A_{0}^{2} / F_{0}$ (Nakamura, 1996, 1997, 2000) for assessing the liquefaction potential in the case of earthquake. The estimated (SIV) values range from 11 to 95 . These values were used to produce a $3 \mathrm{D}$ representation map shows the spatial distribution of $\mathrm{Kg}$ value at the investigated area (Figure 16). This map showed that, the highest values were observed at the middle part of the mapped area; while the lower values observed at the western, 
eastern, and southern parts of the area. These results are consistent with amplification level distribution, where the area of relatively high $\mathrm{Kg}$ values corresponds to the area of high amplification level and vice versa. Nakamura (1997) concluded that the earthquake damage affects the areas have seismic vulnerability index in the range between 20 and 100 more than those have a vulnerability index values less than 5. Accordingly, the investigated area is likely tended to greatly amplify the movement of the earth in the event of an earthquake, due to the presence of soft sediments (Herak et al., 2009).

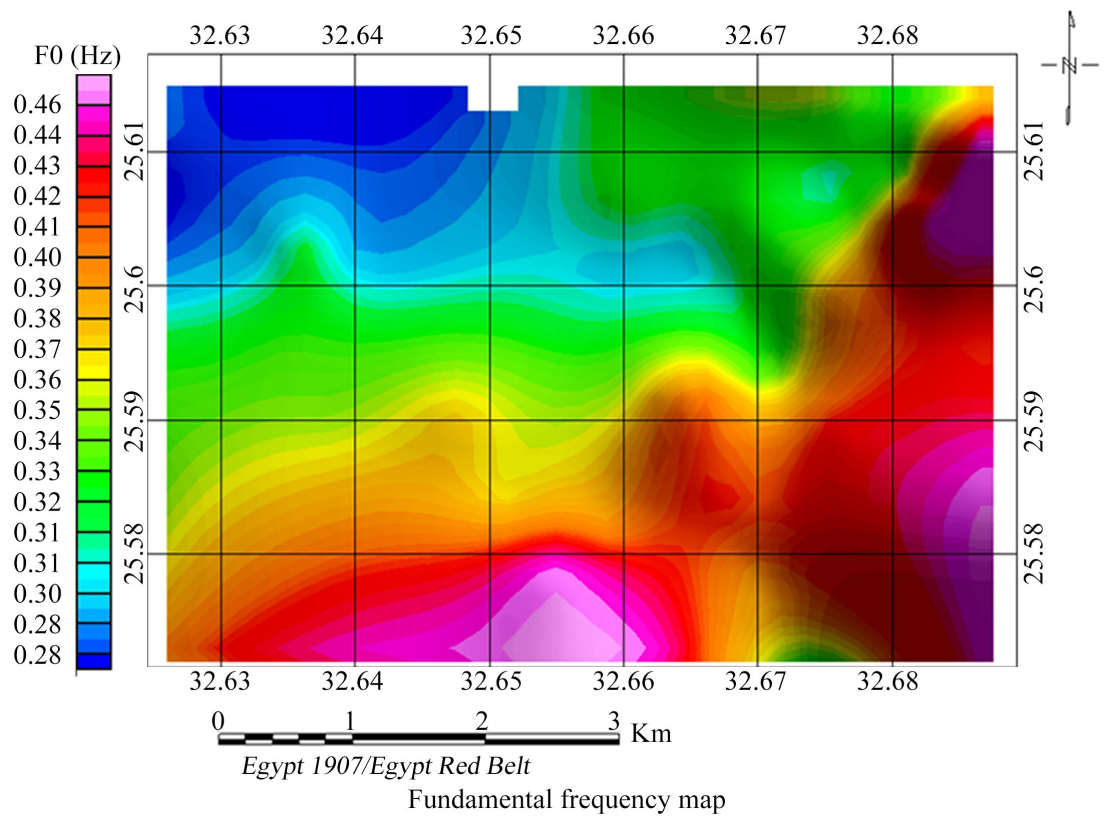

Figure 14. Spatial allocation map of the fundamental frequency $\left(F_{0}\right)$ at the study area.

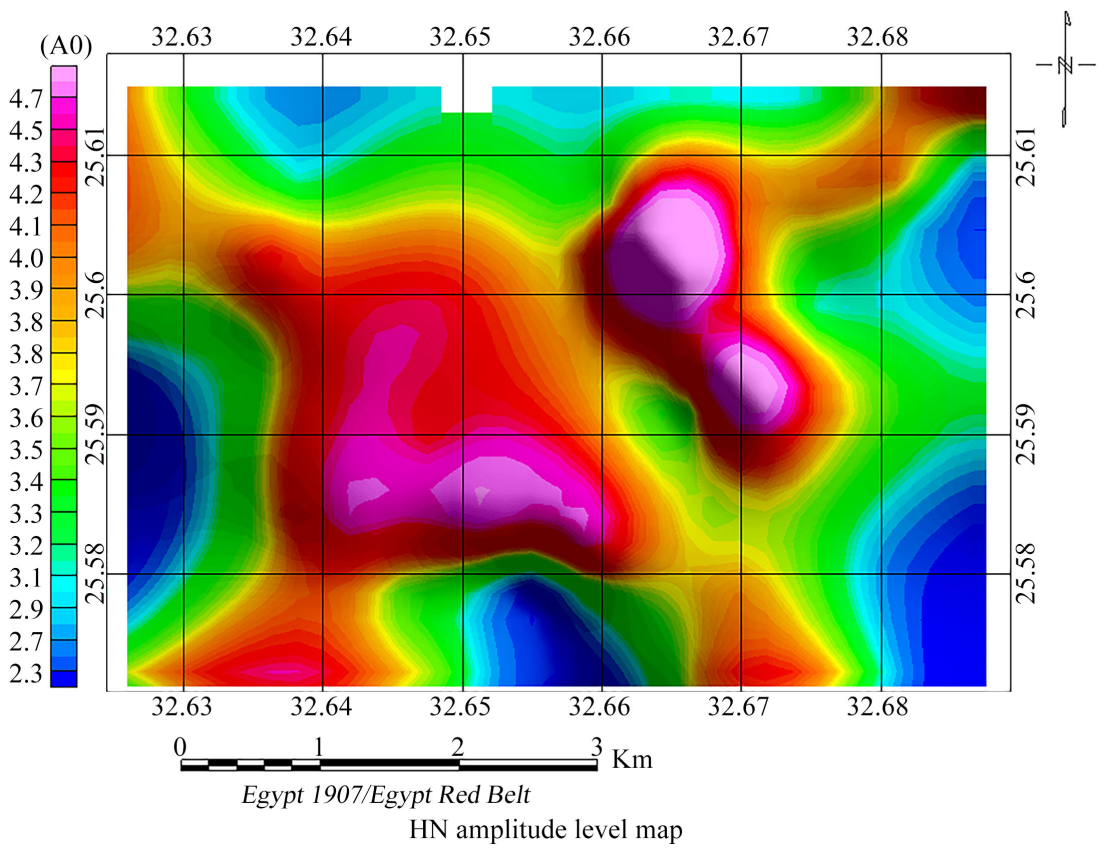

Figure 15. Spatial allocation map of amplification factors $\left(A_{0}\right)$ at the study area. 


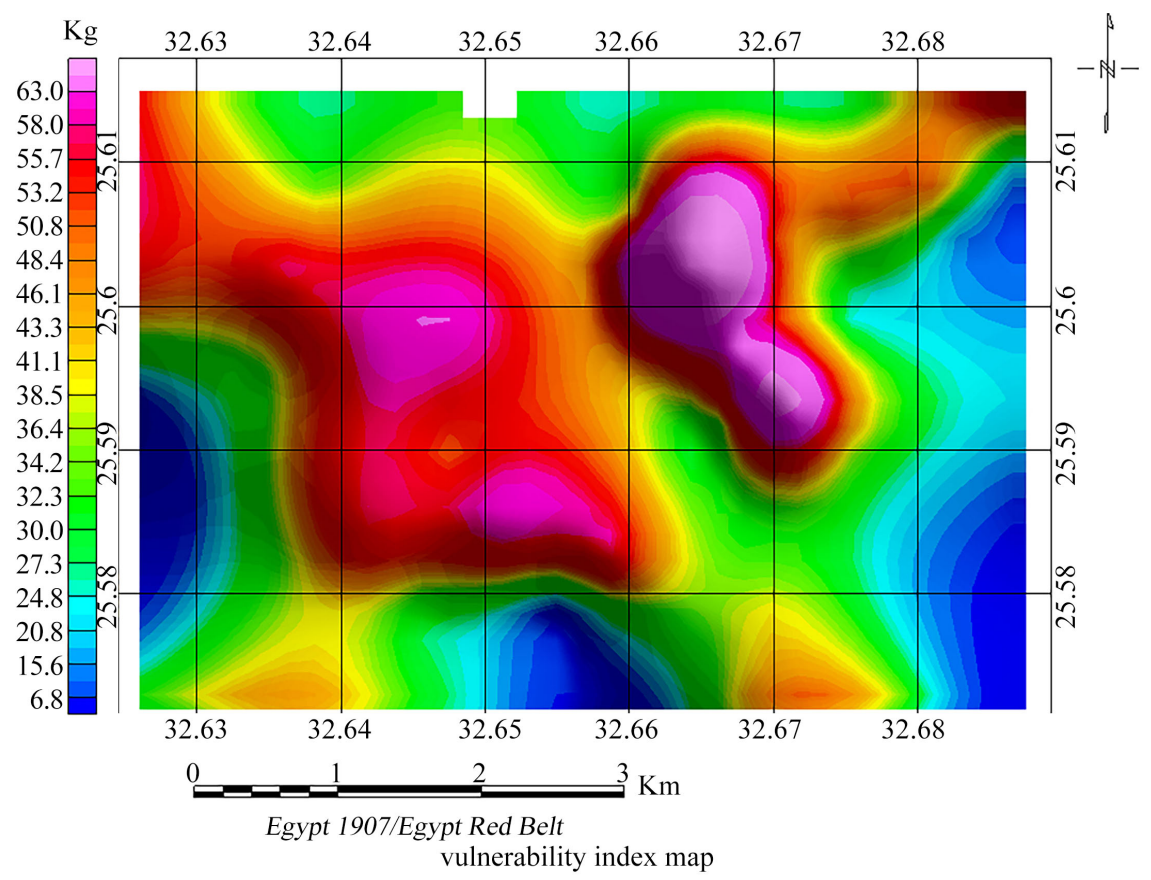

Figure 16. Spatial distribution of the seismic vulnerability index $(K g)$ at the study area.

When the resonance frequency $\left(F_{0}\right)$ of the soil coinciding with the natural frequency of the buildings and structures, in this case the seismic ground motion will create resonance phenomenon of building and damaged of structures will expected (Mukhopadhyay \& Bormann, 2004; Gosar, 2007, 2010).

The zonation map of fundamental frequency could be explicated with consideration of building rise and its fundamental frequency of oscillation to calculate the numbers of stories at which the resonance phenomena may be occurred. A simple approximation for potential building resonance is provided by (Gosar, 2009) as following:

$$
F=10 / \text { Stories numbers }
$$

For avoiding the soil-structure resonance, the soil frequency mustn't match building frequency. The fundamental frequency of soil at the study area exhibits low values less than $0.5 \mathrm{~Hz}$, at this point and by using equation 8 , buildings above 21 floors may be resonate and damaged in the case of possible earthquake. Due to the very low soil frequency, the taller building expected to be the more possibility of soil-structure resonance.

\section{Conclusion}

The present work includes implementation of 41 microtremors measurement points using Nakamura's technique for the purpose of estimating the site effect at the new Luxor city site as well as assessment of the liquefaction potential by calculating the seismic vulnerability index. $\mathrm{H} / \mathrm{V}$ ratio results show a low resonance frequency value at the investigated area, where it varies from $0.28-0.47 \mathrm{~Hz}$. Otherwise, the amplification factors have a value between 2.3 and 6.8 . These re- 
sults indicate that, the site characterized by the presence of thick soft sediments overlying a hard bed rock, with a high impedance contrast between them, consequently these sediments expected to amplify the ground motion. The calculated $(K g)$ reflects a high value ranging from 11 to 95 . These values comply with the obtained amplification levels result, so a potential deformation is highly expected due to liquefaction during earthquake occurrence. $\mathrm{H} / \mathrm{V}$ spectral ratio method, proved its efficiency for assessing soil-resonance structure. In this manner, the taller buildings 21 stories and more, the higher potential of soil-resonance structures due to the low fundamental frequency of soil at the study area. $\mathrm{H} / \mathrm{V}$ spectral ratio results reflect low values of the frequency $\left(F_{0}\right)$ and higher values of the $(K g)$ and $\left(A_{0}\right)$, indicating an expected damage or deformation due to ground motion amplification or liquefaction in case of earthquake occurrence. Finally, we can say that, HVSR method proved its efficiency for site effect estimation and determined the dynamic characteristics of the foundation soil. The application of microtremors is a fast, non-invasive, and cost-efficient method requiring minimal man-power, thus making it an appealing technique.

\section{Acknowledgements}

Authors highly appreciate the great collaboration made by Dr. Sayed Mohamed (National Research Institute of Astronomy and Geophysics (NRIAG), Aswan, Egypt) during the field works of the present study.

\section{Conflicts of Interest}

The authors declare no conflicts of interest regarding the publication of this paper.

\section{References}

Abd El-Rahman, M. A. (1980). Geology of the Area Southeast of Qena with Special Reference to the Phosphate Deposits (184 p). M.Sc. Thesis, Assiut University.

Abdel-aal, A. K. (2018). New Relationship between Fundamental Site Frequency and Thickness of Soft Sediments from Seismic Ambient Noise. Journal of Seismology, 22, 1315-1323. https://doi.org/10.1007/s10950-018-9753-x

Abdel-Rahman, K., Abd el-aal, A. K., El-Hady, S., Mohamed, A. A., \& Abdel-Moniem, E. (2012). Fundamental Site Frequency Estimation at New Domiat City, Egypt. Arabian Journal of Geosciences, 5, 653-661. https://doi.org/10.1007/s12517-010-0222-2

Abudeif, A. M., Fat-Helbary, R. E., Mohammed, M. A., El-Khashab, H. M., \& Masoud, M. M. (2019). Estimation of the Site Effect Using Microtremor Technique at New Akhmim City, Akhmim, Sohag, Egypt. Russian Geology and Geophysics, 60, 231-239. https://doi.org/10.15372/RGG2019036

Ansal, A., Biro, Y., Erken, A., \& Guleru, U. (2004). Seismic Microzonation: A Case Study. In A. Ansal (Ed.), Recent Advances in Earthquake Engineering and Microzonation (Vol. 1, pp. 253-256). Kluwer Academic Publishers. https://doi.org/10.1007/1-4020-2528-9 9

Bard, P. (2000). Lecture Notes on "Seismology, Seismic Hazard Assessment and Risk Mitigation”. International Training Course, CFZ. 
Bindi, D., Parolai, S., Spallarossa, D., \& Cattaneo, M. (2000). Site Effects by H/V Ratio: Comparison of Two Different Procedures. Journal of Earthquake Engineering, 4, 97-113. https://doi.org/10.1080/13632460009350364

Borcherdt, R. D., Glassmoyer, G., Der Kiureghian, A., \& Cranswick, E. (1989). Results and Data from Seismologic and Geologic Studies Following Earthquakes of December 7, 1988, near Spitak, Armenia S.S.R. USGS Numbered Series, Open File Report, 89-163A. https://doi.org/10.3133/ofr89163A

Burjanek, J., Edwards, B., \& Fah, D. (2014). Empirical Evidence of Local Seismic Effects at Sites with Pronounced Topography: A Systematic Approach. Geophysical Journal International, 197, 608-619. https://doi.org/10.1093/gji/ggu014

Dunand, F., Bard, P., Chatelain, J., Guéguen, P., Vassail, T., \& Farsi, M. (2002). Damping and Frequency from Randomdec Method Applied to in Situ Measurements of Ambient Vibrations. 12th European Conference on Earth quake Engineering, London, $9^{\text {th }}-13^{\text {th }}$ September 2002, 869.

El Hossary, M. (1994). Hydrogeological and Hydrochemical Studies on Luxor Area, Southern Egypt. M.Sc. Thesis, Ain Shams University.

El-Eraki, M., Mohamed, A. A., El-Kenawy, A. A., Toni, M. S., \& Imam, S. M. (2012). Engineering Seismological Studies in and around Zagazig City, Sharkia, Egypt. NRIAG Journal of Astronomy and Geophysics, 1, 141-151.

https://doi.org/10.1016/j.nrjag.2012.12.009

Fat-Helbary, R. E., El-Faragawy, K. O., \& Hamed, A. (2019). Application of HVSR Technique in the Site Effects Estimation at the South of Marsa Alam City, Egypt. Journal of African Earth Sciences, 154, 89-100. https://doi.org/10.1016/j.jafrearsci.2019.03.015

Gosar, A. (2007). Microtremor HVSR Study for Assessing Site Effects in the Bovec Basin (NW Slovenia) Related to $1998 \mathrm{Mw} 5.6$ and $2004 \mathrm{Mw} 5.2$ Earthquakes. Engineering Geology, 91, 178-193. https://doi.org/10.1016/j.enggeo.2007.01.008

Gosar, A. (2009). A Microtremor HVSR Study of the Seismic Site Effects in the Area of the Town of Brežice (Se Slovenia). Acta Geotechnica Slovenica, 6, 30-45.

Gosar, A. (2010). Site Effects and Soil-Structure Resonance Study in the Kobarid Basin (NW Slovenia) Using Microtremors. Natural Hazards and Earth System Sciences, 10, 761-772. https://doi.org/10.5194/nhess-10-761-2010

Gosar, A. (2012). Determination of Masonry Building Fundamental Frequencies in Five Slovenian Towns by Microtremor Excitation and Implications for Seismic Risk Assessment. Natural Hazards, 62, 1059-1079. https://doi.org/10.1007/s11069-012-0138-0

Gosar, A. (2017). Study on the Applicability of the Microtremor HVSR Method to Support Seismic Microzonation in the Town of Idrija (W Slovenia). Natural Hazards and Earth System Sciences, 17, 925-937. https://doi.org/10.5194/nhess-17-925-2017

Herak, D., Herak, M., \& Tomljenović, B. (2009). Seismicity and Earthquake Focal Mechanisms in North-Western Croatia. Tectonophysics, 465, 212-220.

https://doi.org/10.1016/j.tecto.2008.12.005

Kamel, E. R. (2004). Geology of Luxor Area and Its Relationship to Groundwater Uprising under the Pharaohs Temples. M.Sc. Thesis, Aswan Faculty of Science, South Valley University.

Konno, K., \& Ohmachi, T. (1998). Ground-Motion Characteristics Estimated from Spectral Ratio between Horizontal and Vertical Components of Microtremor. Bulletin of the Seismological Society of America, 88, 228-241.

Meneisy, A. M., Toni, M., \& Omran, A. A. (2020). Soft Sediment Characterization Using Seismic Techniques at Beni Suef City, Egypt. Journal of Environmental and Engineer- 
ing Geophysics, 25, 391. https://doi.org/10.32389/JEEG19-069

Meunier, P., Hovius, N., \& Haines, J. A. (2008). Topographic Site Effects and the Location of Earthquake Induced Landslides. Earth and Planetary Science Letters, 275, 221-232. https://doi.org/10.1016/j.epsl.2008.07.020

Milana, G., Azzara, R. M., Bertrand, E., Bordoni, P., Cara, F., Cogliano, R., Cultrera, G., Di Giulio, G., Duval, A. M., Fodarella, A., Marcucci, S., Puccilo, S., Regnier, J., \& Riccio, G. (2011). The Contribution of Seismic Data in Microzonation Studies for Downtown L'Aquila. Bulletin of Earthquake Engineering, 9, 741-759. https://doi.org/10.1007/s10518-011-9246-6

Ministry of industry and Mineral Resources (2006). Geologic Map of Luxor (Al UQSUR) Arab Republic of Egypt Scale 1:100000.

Mohamed, A., Ali, S. M., \& Mostafa, A. (2020). Estimation of Seismic Site Effect at the New Tiba City Proposed Extension, Luxor, Egypt. NRIAG Journal of Astronomy and Geophysics, 9, 499-511. https://doi.org/10.1080/20909977.2020.1784697

Mohamed, A., Fat-Helbary, R., Basheer, A. A., \& Dojcinovski, D. (2013). Using Ambient Vibrations for Site Characterization at the New Aswan University Site, Southern Egypt. SE50EEE International Conference on Earthquake Engineering, Macedonia, 29-31 May 2013, 1-8.

Mohamed, A., Lindholm, C., \& Girgis, M. (2015). Site Characterization and Seismic Site Response Study of the Sahary Area, South Egypt. Acta Geodynamica et Geomaterialia, 12, 427-436. https://doi.org/10.13168/AGG.2015.0032

Molnar, S., Cassidy, J. F., Castellaro, S., Cornou, C., Crow, H., Hunter, J. A., Matsushima, S., Sanchez-Sesma, F. J., \& Yong, A. (2018). Application of Microtremor Horizontal-to-Vertical Spectral Ratio (MHVSR) Analysis for Site Characterization: State of the Art. Surveys in Geophysics, 39, 613-631. https://doi.org/10.1007/s10712-018-9464-4

Mukhopadhyay, S., \& Bormann, P. (2004). Low Cost Seismic Microzonation Using Microtremor Data: An Example from Delhi, India. Journal of Asian Earth Sciences, 24, 271-280. https://doi.org/10.1016/j.jseaes.2003.11.005

Nakamura, Y. (1989). A Method for Dynamic Characteristics Estimation of Sub-Surface Using Microtremor on the Ground Surface. Railway Technical Research Institute, Quarterly Reports, 30, 25-33.

Nakamura, Y. (1996). Real-Time Information Systems for Hazards Mitigation. Proceedings of the Xth World Conference on Earthquake Engineering, Acapulco, 23-26 June 1996, 2134.

Nakamura, Y. (1997). Seismic Vulnerability Indices for Ground and Structures Using Microtremor. World Congress on Railway Research, Florence, Italy, November 1997, $1-7$.

Nakamura, Y. (2000). Clear Identification of the Fundamental Idea of Nakamura's Technique and Its Applications. 12th World Conference on Earthquake Engineering, New Zealand (CD-ROM) Paper No. 2656, 8 p.

Nogoshi, M., \& Igarashi, T. (1971). On the Amplitude Characteristics of Microtremor (Part 2). Journal of the Seismological Society of Japan, 24, 26-40.

Panzera, F., Lombardo, G., D’Amico, S., \& Galea, P. (2013). Chapter 5. Speedy Techniques to Evaluate Seismic Site Effects in Particular Geomorphologic Conditions: Faults, Cavities, Landslides and Topographic Irregularities. In S. D'Amico (Ed.), Engineering Seismology, Geotechnical and Structural Earthquake Engineering (pp. 102-138). InTech Open. https://doi.org/10.5772/55439

Picozzi, M., Parolai, S., \& Albarello, D. (2005). Statistical Analysis of Noise Horizontal to 
Vertical Spectral Ratios (HVSR). Bulletin of the Seismological Society of America, 95, 1779. https://doi.org/10.1785/0120040152

Reiter, L. (1990). Earthquake Hazard. Analysis: Issues and Insights (p. 254). Columbia University Press.

Said, R. (1962). The Geology of Egypt. Elsevier.

Said, R. (1981). The Geological Evaluation of the River Nile (p. 151). Springier-Verlag. https://doi.org/10.1007/978-1-4612-5841-4

Said, R. (1990). The Geology of Egypt (2nd ed.). Elsevier.

SESAME (2004). Guidelines for the Implementation of the H/V Spectral Ratio Technique on Ambient Vibrations: Measurements, Processing and Interpretation (pp. 1-62). SESAME European Research Project WP12.

Singh, S. K., Lermo, J., Dominguez, T., Ordaz, M., Espinosa, J. M., Mena, E., \& Quaas, R. (1988). The Mexico Earthquake of September 19, 1985-A Study of Amplification of Seismic Waves in the Valley of Mexico with Respect to a Hill Zone Site. Earthquake Spectra, 4, 653-673. https://doi.org/10.1193/1.1585496

Wathelet, M. (2010). Geopsy Project. http://www.geopsy.org/index.html 